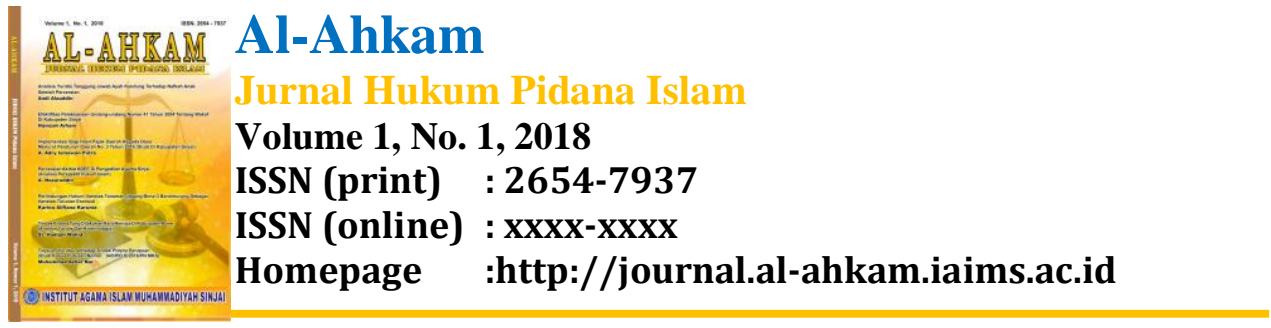

\title{
PERLINDUNGAN HUKUMVARIETAS TANAMAN JAGUNG BIMA-3 BANTIMURUNG SEBAGAI VARIETAS TURUNAN ESENSIAL
}

\author{
Karina AlifianaKarunia \\ IAI Muhammadiyah Sinjai, Jl. Sultan Hasanuddin No. 20, Sinjai
}

\begin{abstract}
Abstrak
NilaipotensialVarietastanaman, seharusnyadiikutidenganperlindunganhukum yang

bisamelindungidariBioprospectingataupencurianvarietastanamanolehberbagaipi hak.PenelitianinibertujuanuntukmengetahuidanmemahamiPerlindungan hukum jagung Bima-3 Bantimurung sebagai Varietas Turunan Esensial ditinjau dari Undang-undang No. 29 Tahun 2000 tentang Perlindungan Varietas Tanaman dan Peraturan Pemerintah No. 13 Tahun 2004 Tentang Penamaan, Pendaftaran, dan Penggunaan Varietas Asal untuk Pembuatan Varietas Turunan Esensial. Penelitianinimerupakantipepenelitiannormatifempirik.Data primer dansekunderdianalisissecarakualitatif.Setelahitu, data dideskripsikandenganmenelaahpermasalahan yang ada, menggambarkan, menguraikanhinggamenjelaskanpermasalahan-permasalahan yang berkaitandenganpenelitianini.Hasilpenelitianmenunjukkanbahwaketentuandalam Undang-undang No. 29 Tahun 2000 tentang Perlindungan Varietas TanamandanPeraturanPemerintah No. 13 Tahun 2004 tentangpenamaan, pendaftaran,

danpenggunaanvarietasasaluntukpembuatanvarietasturunanesensialdalammembe rikanPerlindunganJagung Bima-3 BantimurungsebagaiVarietasTurunanEsensialtelahdiaturmengenaiketentuanadmi nistrasidanteknisnya, namun, tidakadapenjelasantentangperbedaanantaravarietasasaldanvarietasturunanesensi alselainkewajibanmembuatperjanjianbagipemuliavarietasturunanesensial.

SedangkanperlindunganterhadapbenihJagung Bima-3 Bantimurung yang merupakantanamanmusimandenganjenishibrida yang benihnyahanyadapatditanamsatu kali, setelahhabis, kembalilagikeprodusenbenih, varietasinitelahdilindungidenganadanyasertifikatdansistempengawasansertapeng ontrolan yang baikdaripihakBalitserealdanPihakSwasta, sehinggapelanggarandapatdiproteksitanpamelalui proses pengadilan
\end{abstract}

Kata kunci: Perlindunganhukum, KekayaanIntelektual, perlindunganvarietastanaman, Jagung Bima-3 Bantimurung. 


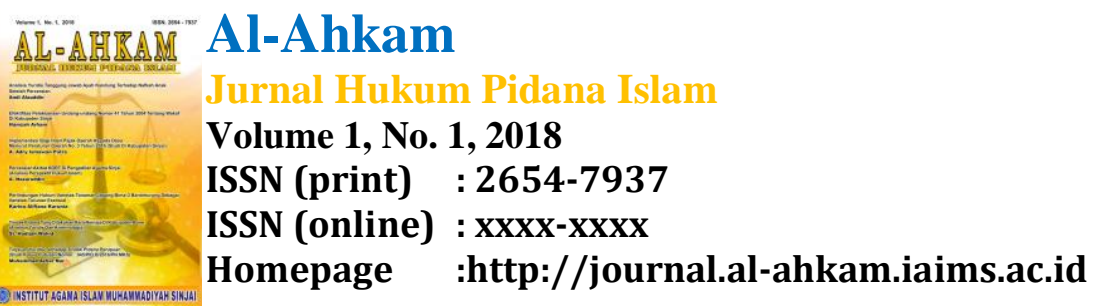

PENDAHULUAN 
Indonesia merupakan negara yang memiliki tingkat keanekaragaman hayati yang sangat tinggi.Hal ini dibuktikan dengan pengakuan dunia terhadap Indonesia sebagai nega mega biodiversity dan menempati urutan kedua setelah Brazil menurut The World Conservation Monitoring Center. Dengan sumber daya alam yang berlimpah ini, Indonesia memiliki modal yang cukup untuk bersaing dengan negara lain, terutama setelah Indonesia turut serta dalam komunitas global yang ditandai dengan ikut dalam meratifikasi beberapa kesepakatan internasional yakni, perjanjian WTO/GATT, TRIPS, dan beberapa kesepakatan Internasional lainnya.Oleh karena itu, diperlukan upaya untuk dapat meningkatkan produktivitas, daya saing, dan kualitas komoditas tanaman. Solusinya adalah dengan diadakannya kegiatan pemuliaan tanaman oleh para pemulia.Pemuliaan tanaman sendiri didefinisikan sebagai serangkaian kegiatan penelitian dan pengembangan genetik tanaman (modifikasi gen ataupun kromosom) untuk merakit kultivar/varietas unggul yang memiliki kualitas tinggi seperti perbaikan terhadap warna, rasa, aroma, daya simpan, dan kandungan protein yang berguna bagi kehidupan manusia.

Faktor inilah yang menjadi salah satu latar belakang lahirnya Undang-undang Nomor 29 Tahun 2000 tentang Perlindungan Varietas Tanaman (yang selanjutnya disebut Undang-Undang tentang Perlindungan Varietas Tanaman).Dengan ini, para pemulia tidak perlu ragu dan khawatir untuk membuat suatu varietas tanaman baru karena telah diberikan perlindungan khusus bagi varietas tersebut dan hak eksklusif bagi pemulia.Akan tetapi, kenyataan yang terjadi saat ini, beberapa pemulia, hanya menghasilkan berbagai varietas unggul baru kemudian diperdagangkan di masyarakat tanpa melakukan perlindungan terlebih dahulu.Hal ini disebabkan pemahaman yang masih sangat kurang.Varietas tanaman merupakan suatu varietas yang pada dasarnya merupakan hasil penemuan yang dapat diturunkan.Dalam hal ini, suatu varietas tanaman dapat dikembangkan dari varietas tanaman hasil pemuliaan sebelumnya menjadi suatu varietas tanaman yang baru dan memiliki sifat yang lebih unggul dari varietas asalnya, yakni varietas turunan esensial. Oleh karena itu, kini para pemulia mulai menghasilkan varietas "generasi kedua" tersebut yang jika dikomersialkan akan mendapat tanggapan yang sangat positif dari masyarakat, namun kendala yang dihadapi saat ini adalah kurangnya peran dari pihak swasta 


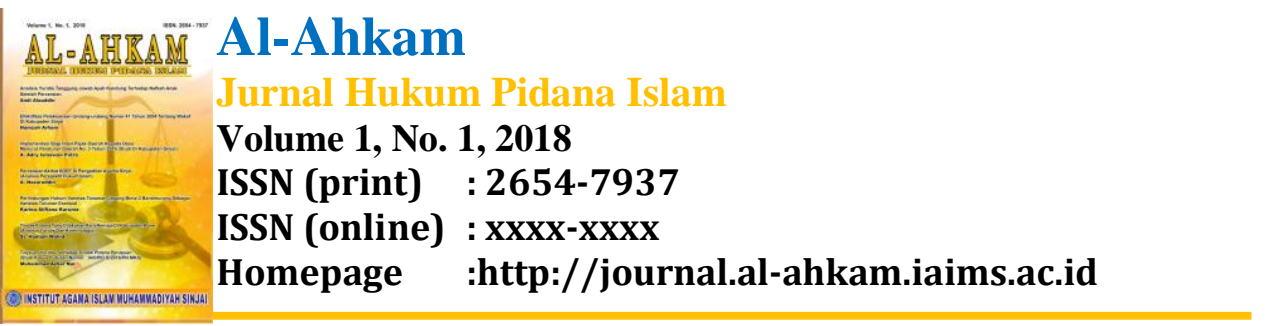

dalam negeri untuk memproduksi, memperdagangkan, terutama menghasilkan varietas hasil pemuliaan dan turunan esensialnya.

Hal ini menjadi potensi dan peluang yang sangat baik bagi Indonesia untuk memanfaatkan nilai potensial dari varietas hasil pemuliaan dan varietas "generasi kedua" tersebut, yang dapat dilihat dari keuntungan yang didapatkan dari berbagai penyalahgunaan dan pelanggaran yang dilakukan oleh perusahaan-perusahaan asing. Varietas turunan esensial telah dikembangkan oleh beberapa pihak, salah satunya adalah dari Balai Penelitian Serealia (selanjutnya disingkat Balitsereal) yang telah menghasilkan beberapa varietas hasil pemuliaan. yang kemudian dikembangkan menjadi varietas turunan esensial. Sebagai contohnya adalah Jagung Bima-3 Bantimurung. Jagung ini memiliki banyak keunggulan dan telah didaftarkan namun permasalahannya adalah jagung ini telah diperdagangkan sebelum terbit sertifikat perlindungan varietas tanamannya dan banyaknya pihak yang ingin mengembangkan bibit Jagung Bima-3 Bantimurung tersebut. Maka keberadaan Undang-Undang maupun peraturan lain yang mengatur tentang hal ini, sangatlah dibutuhkan. Terutama dengan status hukum Jagung Bima-3 Bantimurung jika terjadi penyalahgunaan ketika diperdagangkan. Hal ini dimaksudkan agar seluruh lapisan masyarakat dan Balitsereal pada khususnya memahami isi dari Undang-Undang dan Peraturan tersebut yang dalam hal ini Undang-Undang Perlindungan Varietas Tanaman dan Peraturan Pemerintah No. 13 Tahun 2004 tentang Penamaan, Pendaftaran, dan Penggunaan Varietas Asal untuk Pembuatan Varietas Turunan Esensial.Oleh karena itupenelitian ini akan mengkaji dan membahas Pengaturan dalam Undang-Undang Nomor 29 Tahun 2000 tentang Perlindungan Varietas Tanaman dan Peraturan Pemerintah No. 13 Tahun 2004 tentang Penamaan, Pendaftaran, dan Penggunaan Varietas Asal untuk Pembuatan Varietas Turunan Esensial dalam memberikan perlindungan terhadap Varietas Turunan Esensial yang dalam hal ini Jagung Bima-3 Bantimurung sebagai salah satu produk yang termasuk dalam Varietas Turunan Esensial.

\section{METODEPENELITIAN}




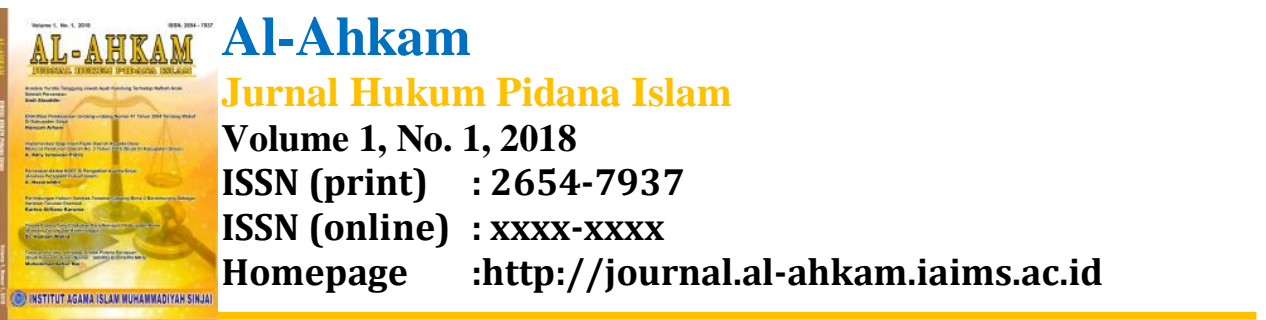

\section{A. TipePenelitian}

Penelitianinidilakukanmenurutmetodepenelitian yang berlaku, yaknimetodepenelitianhukum.Metodeadalahtatacaraatauprosedur yang harusditempuhdalammelakukankegiatan, dalamhalinikegiatantersebutadalahkegiatanpenelitianhukum(Purwaka, 2007). Penelitianhukum yang

digunakandalampenelitianiniadalahnormatif.Empiris.Yakniuntukmengkajiaspekhukumdanpelaks anaanaspekhukumtersebut di lapangan.DalamhaliniberkaitandenganPerlindunganHukumJagung Bima-3 Bantimurungsebagaivarietasturunanesensial.

\section{B. LokasiPenelitian}

Penelitianinidilakukan di BalaiPenelitianSerealia (selanjutnyadisingkatBalitsereal) Maros.PenentuanlokasipenelitiantersebutdikarenakanBalitserealmerupakanbalai yang mengembangkandanmemanfaatkantanamanserealiadalamsegalahalkhususnyasebagaibahanpanga nsepertimengenaiJagung.Selainitu, penelitianjugadilakukan di KementerianPertaniansebagaikementerian yang bertanggungjawablangsungterhadapPerlindunganVarietasTanamanyakniKementerianPertanian di Jakarta.

\section{JenisdanSumber Data}

Sumber data dalampenelitianiniterdiridari data primer dan data sekunder. Data primer adalah data yang diperolehlangsung di lapangan (field research), yang dilakukanmelaluiwawancarainstansi yang berkenaandenganPerlindunganVarietasTanamanyakniKementerianPertanian, danlembagaterkait yang melakukanpenelitiandanmemahamitentangJagung Bima-3 BantimurungdalamhaliniPemulia di BalaiPenelitianTanamandanSerealia (Balitsereal). Data sekunderyaitu data yang tingkatannyakeduabukan yang utama.Data sekunderberupabahan-bahanhukum primer, sekunderdantersier.

\section{TeknikPengumpulan Data}


Volume 1, No. 1, 2018

ISSN (print) : 2654-7937

ISSN (online) : xxxx-xxxx

Homepage :http://journal.al-ahkam.iaims.ac.id

Di dalampenelitianhukumuntukkeperluanakademis pun bahan non hukumdapatmembantu. Dalampenelitianinidikumpulkan pula bahan non hukum, untukmembantupenelitianiniyakni: literaturberupabuku-buku, hasilpenelitian, karyailmiah, laporan, dan lain-lain, padabidanghukummenyangkut KI dan di bidangpertanianmenyangkutJagung Bima-3 Bantimurung. Teknik Pengumpulan dapat dilakukan dengan Teknik Wawancara dan Studi Kepustakaan/ Dokumentasi.Teknik Wawancara yaitu usaha pengumpulan data yang dilakukan dengan cara mengadakan tanya jawab berkaitan dengan kegiatan penelitian. Sedangkan studi kepustakaan/dokumentasi Yaitu menelaah bahan-bahan tertulis berupa buku-buku, dokumen resmi peraturan perundang-undangan, serta sumber tertulis lain yang berkaitan dengan masalah yang diteliti.

\section{E. MetodeAnalisis Data}

Seluruh data yang diperoleh dalam penelitian, baik data primer dan data sekunder, dianalisis dengan menggunakan teknik analisis kualitatif. Setelah itu dideskripsikan, dengan menelaah permasalahan yang ada, menggambarkan, menguraikan, hingga menjelaskan permasalahan-permasalahan yang berkaitan dengan penelitian ini. Penggunaan metode deskriptif ini dimaksudkan untuk memperoleh gambaran yang baik, jelas, dan dapat memberikan data sedetail mungkin tentang objek yang diteliti, dalam hal ini untuk menggambarkan bagaimana perlindungan hukum yang diberikan peraturan perundang-undangan KI terhadap PerlindunganVarietastanamanJagung Bima-3 Bantimurungsebagaivarietasturunanesensial

\section{F. HasilPenelitian}

Jagung Bima-3 Bantimurung ini merupakan produk Balitsereal yang berasal dari seleksi tanaman dan silang tunggal dari betina Nei 9008 dan jantan Mr-14, yang juga merupakan jantan yang digunakan untuk silang tunggal Bima1 dan Bima-2 Bantimurung, varietas asal dari Jagung Bima-3 Bantimurung, dandapatdigologkansebagaivarietasturunanesensial. Jagung ini memiliki kelebihan dari varietas asalnya, yakni stay green (daunnya dapat dijadikan pakan unggas dan batangnya dapat dijadikan pakan ternak), tahan terhadap penyakit bulai (hama penyakit tanaman 
yang dapat menyebabkan rebahnya tanaman Jagung), batangnya besar sehingga tidak mudah rebah, produktivitas yang tinggi, dan keunggulan lainnya. Oleh karena itu, Balitsereal melakukan pendaftaran untuk mendapatkan perlindungan hukum dan pada tahun 2009 diterbitkan sertifikat bagi Jagung Bima-3 Bantimurung dan menjadi varietas yang dilindungi (Kementrian Pertanian), Ketika telah dipasarkan di masyarakat, Jagung ini mendapatkan respon yang sangat positif, karena keunggulan yang dimilikinya, dan sudah menyaingi bahkan mengungguli produk dari perusahaan asing seperti Pioneer, Bisi, Monsanto, dan sebagainya.

Namun, pemberian sertifikat itu bukan menjadi usaha akhir untuk mendapatkan perlindungan hukum, karena yang paling penting adalah bagaimana pengawasannya dilapangan setelah dikomersilkan ke masyarakat luas. Apalagi ketika PihakBalitsereal yang pada awalnya memberi lisensi eksklusif yang kemudian dicabut, kini memberikan lisensi biasa dengan tujuan agar terjadi pemerataan antara swasta/pengelola dan masyarakat (dalam hal ini, petani, sebagai mitra swasta). Oleh karena setiap pihak dapat menggunakan lisensi tersebut, maka kendala yang dihadapi adalah apabila baik dari pihak swasta maupun petani melakukan penyalahgunaan dengan mengambil benih tanpa izin dari Balitsereal kemudian memperdagangkan dengan nilai jual yang lebih murah dibanding harga pasaran, seperti contoh pada kasus yang dialami oleh petani yang dituduh mengambil dan mengembangkan benih Jagung dari PT. BISI, kemudian menjualnya dengan harga murahdanmelakukansertifikasi liar, dandituntut oleh PT. BISI karena telah mengalami kerugian ratusan juta rupiah.

Hasil penelitian yang didapatkan dari perlindungan hukum Jagung Bima-3 Bantimurung sebagai varietas turunan esensial ini diketahui bahwa Oleh karena itu, perlindungan terhadap varietas turunan esensial yang dalam hal ini Jagung Bima-3 Bantimurung sangat dilindungi, begitu pula dengan varietas asal yang digunakan untuk pembuatan Jagung Bima-3 Bantimurung yakni Jagung Bima 1 dan Jagung Bima-2 Bantimurung dan juga pemulia varietas asal yang secara serta merta juga dilindungi dalam peraturan pemerintah ini. Tidak ada perbedaan perlindungan antara varietas asal dan varietas turunan esensial karena kedua varietas tersebut bisa mendapatkan sertifikat melalui prosedur pengajuan permohonan yang telah diatur 


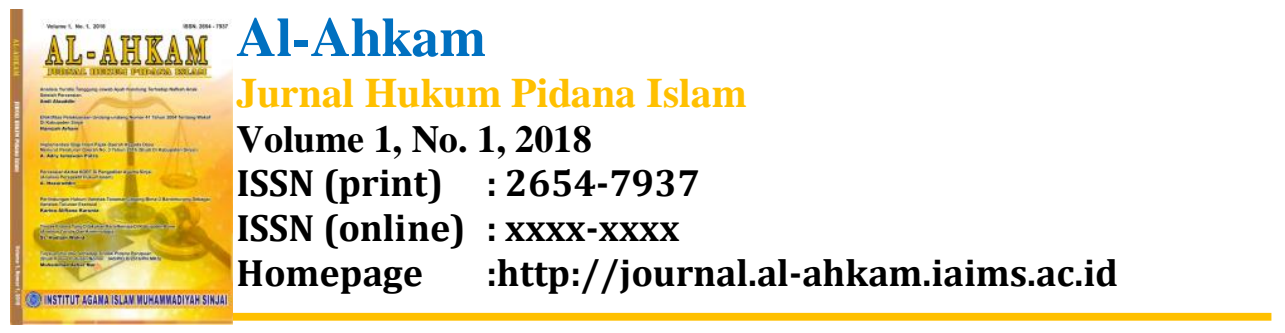

sebelumnya. Hanya saja dalam Peraturan Pemerintah ini Hak Pemulia Varietas Asal sangat diperhatikan dengan adanya kewajiban untuk membuat perjanjian setelah mendapat persetujuan dari pemulia varietas asal dan keharusan untuk menentukan imbalan atau royalti untuk pemulia atas varietas asal yang digunakan dalam pembuatan varietas turunan esensial.

\section{PEMBAHASAN}

PenelitianinimenunjukkanbahwaJagung

Bima-3 BantimurungdapatdiberikanPerlindunganVarietasTanamanyaknipadasubstansivarietasturunanese nsial yang merupakangenerasiselanjutnyadarivarietashasilpemuliaandantelahdidaftarkansertamendapatkans ertifikatnamundengan proses yang lama danrumit agar mendapatperlindunganhukumberupapemberianbuktisertifikattersebut.Karenatelahmemenuhisyar $\begin{array}{llllll}\text { at yang ditetapkandalam } & \text { UU } & \text { No. } & 29 & \text { Tahun } & 2000\end{array}$ tentangPerlindunganVarietasTanamanyaknisebagaiberikut:

\section{Baru.}

Berdasarkan Undang-Undang PVT, suatu varietas dianggap baru apabila pada saat penerimaan permohonan PVT, bahan perbanyakan atau hasil panen dari varietas tersebut belum pernah diperdagangkan di Indonesia atau sudah diperdagangkan tetapi tidak lebih dari setahun, atau telah diperdagangkan di luar negeri tidak lebih dari empat tahun untuk tanaman semusim, dan enam tahun untuk tanaman tahunan. Menurut Warsidi, Kepala Bidang Pelayanan Perlindungan Varietas Tanaman Kementrian Pertanian,syarat kebaruan suatu varietas khususnya jagung Bima-3 Bantimurung ini telah dipenuhi pada pemeriksaan administrasi. Selain itu, benih Jagung Bima-3 Bantimurung ini belum pernah diperdagangkan di luar negeri, sedangkan di dalam negeri sendiri, baru diperdagangkan ketika jagung Bima-3 Bantimurung ini didaftarkan 


\begin{tabular}{|c|c|}
\hline 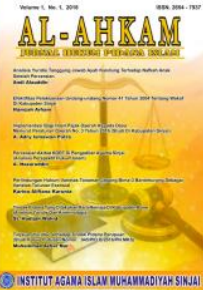 & $\begin{array}{l}\text { Al-Ahkam } \\
\text { Juirnal Hukum Pidana Islam } \\
\text { Volume 1, No. 1, } 2018 \\
\text { ISSN (print) : 2654-7937 } \\
\text { ISSN (online) }: \text { xxxx-xxxx } \\
\text { Homepage } \quad \text { :http://journal.al-ahkam.iaims.ac.id }\end{array}$ \\
\hline
\end{tabular}

dan dalam proses pemeriksaan untuk memperoleh perlindungan dalm bentuk sertifikat oleh pihak PVTPP.

\section{Berbeda}

Dapat dikatakan Berbeda karena Jagung Bima-3 Bantimurung merupakan Jagung Hibrida yang memiliki keunggulan yang lebih dibandingkan jagung hibrida jenis lain, hal ini disebabkan karena sifatnya yang berbeda dengan jagung jenis lain yakni sangat Tahan terhadap penyakit yang disebabkan oleh hama, yakni Penyakit Bulai, Produktivitas yang tinggi, dan memberikan kemanfaatan, maksudnya seluruh bagian Jagung ini dapat dimanfaatkan terutama biomas tongkolnya, ketika sudah panen, tongkolnya berwarna kuning sementara bagian biomas tongkol ke atas masih hijau sehingga bersifat stay green yakni warna batang dan daun masih hijau saat jagung sudah siap untuk dipanen, sehingga sangat baik diintegrasikan dengan ternak seperti sapi. Dan karakter stay green ini tanda toleran kekeringan. Selain itu, bijinya juga dapat dijadikan sebagai pakan ternak ayam.

\section{Stabil}

Stabilitas suatu varietas tanaman dapat diketahui pada saat penanaman berulang-ulang atau melalui perbanyakan suatu siklus khusus dan tidak mengalami perubahan di akhir siklusnya, serta yang terpenting tidak mengalami perubahan pada sifat-sifatnya. Jagung Bima-3 Bantimurung dapat dianggap stabil karena sebelum pelepasan, Bima-3 Bantimurung diuji daya hasil dan stabilitas hasilnya pada tahun 2004 di Bajeng (Sulawesi Selatan), Malang (Jawa Timur), dan beberapa lokasi di Jawa Tengah. Sedangkan pada tahun 2004/2005 di Lanrang (Sulawesi Selatan), Nusa Tenggara Barat, dan Gorontalo. Pada tahun 2005, pengujian dilakukan di Bajeng dan Bone (Sulawesi Selatan), Muneng dan Malang (Jawa Timur), Blora (Jawa Tengah), Lampung, dan Nusa Tenggara Barat, sedangkan pada tahun 2005/2006 di Nusa Tenggara Timur dan Kalimantan Selatan. Pengujian stabilitas kedua jagung hibrida baru tersebut 


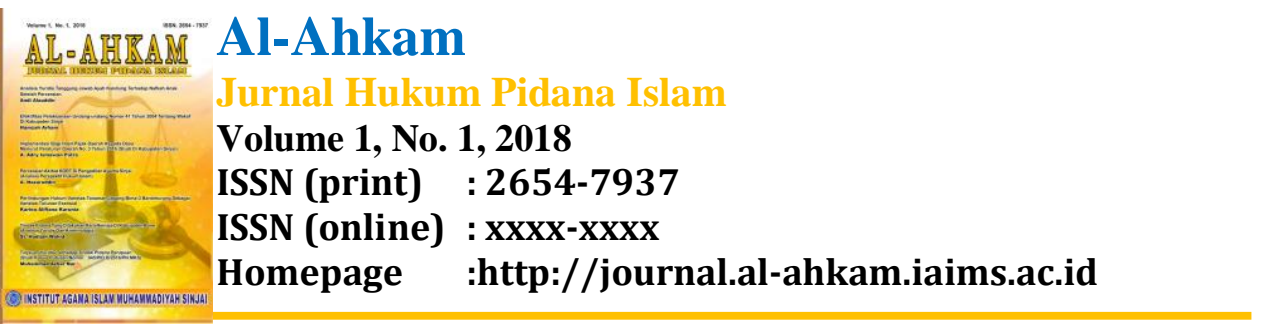

dilakukan di 16 lokasi pada tahun 2004 dan tahun 2005. Selama pengujian, varietas Bima-3 Bantimurung tergolong tahan terhadap penyakit Bulai. Kedua jagung hibrida ini dapat beradaptasi dengan baik pada lahan suboptimal, apalagi dilahan optimal. Selain itu, biji jagung Bima-3 Bantimurung relatif kecil, namun, lebih disukai penangkar karena warnanya terang (jingga). Dari penjelasan di atas, dapat diketahui bahwa Jagung Bima-3 Bantimurung masih memenuhi persyaratan stabilitas dari sebelum pelepasan, setelah pelepasan, dan sampai saat ini karena pada saat proses pertumbuhannya, jagung ini terbukti kebal hama dan penyakit tanaman lainnya, dan beberapa keunggulan yang dapat terlihat dari tampilan fisiknya atau morfologisnya serta memiliki hasil jagung yang memuaskan .

\section{Seragam}

Dari syarat stabilitas diatas, dapat diketahui bahwa Jagung Bima-3 Bantimurung terbukti seragam karena walaupun bervariasi akibat ditanam dengan cara tanam dan pada lingkungan yang berbeda-beda, namun sifat-sifat utamanya yakni tahan penyakit, penampilan tanaman, dan sifat lainnya masih tetap dimiliki sebagai salah satu keunggulan Jagung Bima-3 Bantimurung sebagai turunan dari sifat tetua asalnya.

\section{Diberi penamaan}

Dalam hal pemberian nama Jagung Bima-3 bantimurung, sangat menggambarkan sifat-sifat dasarnya, akan tetapi besar kemungkinan dapat menimbulkan kerancuan dengan indikasi geografis, karena menggunakan nama tempat yakni Bantimurung. Namun, menurut Andi Takdir M, salah satu anggota di Kelompok peneliti Pemuliaan dan Pengelolaan Plasma Nutfah, yang juga merupakan subbagian dari struktur organisasi Balitsereal, ada beberapa hal yang melatar belakang pemberian nama Bima-3 Bantimurung, yaitu:

a. Pemberian Kata bima tidak diperuntukkan untuk daerah Bima, Nusa Tenggara Barat, tetapi diambil dari salah satu nama tokoh di pewayangan, sebagai salah satu identitas asal bangsa 


\section{ALABDIMM Al-Ahkam}

\section{Jurnal Hulkum Pidana Islam}

Volume 1, No. 1, 2018

ISSN (print) : 2654-7937

ISSN (online) : xxxx-xxxx

Homepage :http://journal.al-ahkam.iaims.ac.id

Indonesia, dan juga merupakan nama tetap untuk jenis produk Balitsereal, yakni Jagung Hibrida bersilang tunggal.

b. Pemberian angka 3 karena merupakan generasi ketiga dari Jagung Hibrida produk Balitsereal.

c. Pemberian kata Bantimurung didasarkan pada tempat diselenggarakannya pelepasan Jagung Hibrida dan peresmian Produk Jagung Bima-3 Bantimurung ke pasaran oleh Presiden Soesilo Bambang Yudhoyono.

Setelah memenuhi unsur-unsur tersebut, maka pemulia Jagung Bima-3 Bantimurung ini mengajukan permohonan dan telah mendapatkan sertifikat. Dengan adanya sertifikat, Balitsereal sebagai pemulia memiliki hak eksklusif dan hak substantif. Mengenai Jagung Bima-3 Bantimurung, Jagung ini merupakan Varietas Turunan Esensial yang berasal dari Jagung Bima 1 dan Jagung Bima-2 Bantimurung. Yakni varietas hasil perakitan dari varietas asal dengan menggunakan seleksi tertentu sedemikian rupa sehingga varietas tersebut mempertahankan ekspresi sifat-sifat esensial dari varietas asalnya tetapi dapat dibedakan secara jelas dengan varietas asalnya dari sifat-sifat yang timbul dari tindakan penurunan itu sendiri. Untuk menghasilkan Varietas Tanaman yang unggul seperti Jagung Bima-3 Bantimurung ini, pihak yang sangat berperan penting adalah Pemulia. Sehingga, selain Varietas Tanaman, Pemulia Varietas Tanaman tersebut juga membutuhkan perlindungan sebagai salah satu bentuk penghargaan atas segala kerja keras yang dilakukannya. Namun, perlindungan baik terhadap varietas tanaman maupun pemulia ini hanya dapat diberikan setelah melalui pendaftaran di kantor PVT dalam bentuk pengajuan permohonan ke Kementrian Pertanian atas varietas tanaman yang telah memenuhi syarat baru, unik, seragam, stabil dan diberikan penamaan.

\section{KESIMPULAN DAN SARAN}


Proses pemberian suatu varietas tanaman terlebih dahulu harus memenuhi berbagai unsur berdasarkan UU No. 29 Tahun 2000 atau UU PVT yakni unsur baru, berbeda, seragam, stabil, dan diberi penamaan. Jagung Bima-3 Bantimurung telah memenuhi unsur tersebut dan masih tetap dipertahankan setelah melalui proses pelepasan oleh menteri ke pasaran. Sebagai suatu varietas turunan esensial, perlindungan Jagung Bima-3 Bantimurung juga diatur dalam PP No. 13 Tahun 2004 tentang penamaan, pendaftaran dan penggunaan varietas asal untuk pembuatan varietas turunan esensial. PP ini mengatur tentang tata cara/ kegiatan administratif yang wajib dilakukan oleh pemulia varietas turunan esensial agar mendapat perlindungan. yakni mencakup penamaan yang harus mencirikan identitas varietas asalnya, seperti jagung Bima-3 Bantimurung dari Jagung Bima-2 Bantimurung, pendaftaran dengan prosedur yang telah ditetapkan, dan penggunaan varietas asal dalam hal ini varietas hasil pemuliaan seperti harus mendapat persetujuan terlebih dahulu kepada pemulia varietas asal yang kemudian kewajiban membuat perjanjian antara kedua belah pihak yang harus memuati hak moral dan hak ekonomi varietas asal. Sementara itu, untuk Jagung Bima-3 Bantimurung, tidak memerlukan perjanjian dan persetujuan dari pemulia varietas asal, karena merupakan hasil pemuliaan dari satu badan hukum yang sama yakni Balitsereal. Selain itu, karena dalam UU PVT jelasdibedakanantaravarietas yang termasukvarietasasal, varietaslokal, danvarietasturunanesensial, misalnyamengenaitatacarapendaftaranvarietasturunanesensialharusberkewajibanuntukmembuatp erjanjianantaraparapihak. Namun, padakenyataannya di Kantor PVT, data daninformasimengenaivarietasturunanesensialinitidakbanyakditemukan.Sehinggaperluketeranga ninformasimengenaihalini.

\section{DAFTAR PUSTAKA}

Carsono, N. 2011. PeranPemuliaanTanamandalamMeningkatkanProduksiPertanian di Indonesia.JurnalHukumdanmasyarakat. 


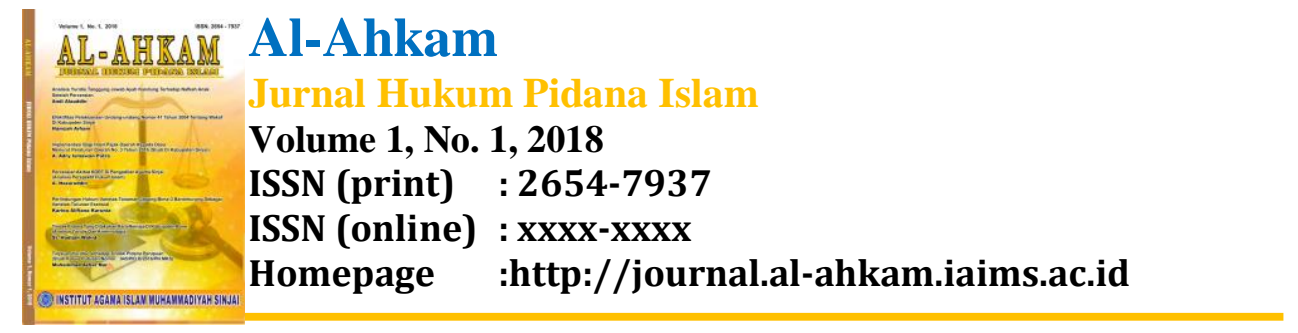

Krisnawati A.\&Saleh G. 2004.PerlindunganHukumVarietasBaruTanaman. Jakarta: RajaGrafindoPersada.

Lubis, E. 2009.PerlindungandanPemanfaatanSumberDayaGenetikBerdasarkan Prinsip Sovereign Right danKekayaanIntelektual. Bandung: Alumni.

Marzuki, P.2011. PenelitianHukum. Jakarta: KencanaPrenada Media Group.

Purwaka, T. 2007. MetodePenelitian. Jakarta: PenerbitUniversitasAtmajaya.

Salim, HS.\&Septiana E. 2013.PenerapanTeoriHukumPadaPenelitianTesisdan Disertasi.

Jakarta: RajaGrafindoPersada.

Warta penelitian dan pengembangan pertanian vol.29, No.4 tahun 2007, Jagung Hibrida Unggul Baru. R. Neni Iriany dan Andi Takdir M, 2007, hlm 3. 